University of Wollongong

Research Online

Australian Institute for Innovative Materials -

Papers

Australian Institute for Innovative Materials

$1-1-2015$

Boosting the efficiency of quantum dot sensitized solar cells up to $7.11 \%$ through simultaneous engineering of photocathode and photoanode

\author{
Yang Bai \\ University of Queensland \\ Chao Han \\ University of Wollongong, ch861@uowmail.edu.au \\ Xinqi Chen \\ University of Wollongong, xc067@uowmail.edu.au \\ Hua Yu \\ University of Queensland \\ Xu Zong \\ Dalian Institute of Chemical Physics
}

See next page for additional authors

Follow this and additional works at: https://ro.uow.edu.au/aiimpapers

Part of the Engineering Commons, and the Physical Sciences and Mathematics Commons

Research Online is the open access institutional repository for the University of Wollongong. For further information contact the UOW Library: research-pubs@uow.edu.au 


\title{
Boosting the efficiency of quantum dot sensitized solar cells up to $7.11 \%$ through simultaneous engineering of photocathode and photoanode
}

\author{
Abstract \\ We demonstrate a new strategy of boosting the efficiency of quantum dot sensitized solar cells (QDSSCs) \\ by engineering the photocathode and photoanode simultaneously. Nanostructured photocathodes based \\ on non-stoichiometric $\mathrm{Cu}_{2-\mathrm{x}} \mathrm{Se}$ electrocatalysts were developed via a simple and scalable approach for \\ $\mathrm{CdS} / \mathrm{CdSe}$ QDs co-sensitized solar cells. Compared to $\mathrm{Cu}_{2} \mathrm{~S} C \mathrm{CE}$, remarkably improved photovoltaic \\ performance was achieved for QDSSCs with $\mathrm{Cu}_{2-x} \mathrm{Se} \mathrm{CEs}$. The superior catalytic activity and electrical \\ conductivity of $\mathrm{Cu}_{2-x} \mathrm{Se} \mathrm{CEs}$ were verified by the electrochemical impedance spectra and Tafel- \\ polarization measurements. To maximize the efficiency enhancement, the photoanodes were optimized \\ by introducing a pillared porous titania composite as the scattering layers for further light harvesting and \\ charge transfer improvement concurrently. The combination of effective $\mathrm{Cu}_{2-\mathrm{x}} \mathrm{Se}$ electrocatalysts and \\ pillared titania scattering layers contributed to one of the best reported efficiencies of $7.11 \%$ for CdS/ \\ CdSe QDs co-sensitized solar cells.

\section{Keywords} \\ sensitized, dot, quantum, efficiency, boosting, cells, up, solar, 7, photoanode, 11, simultaneous, \\ engineering, photocathode \\ Disciplines \\ Engineering | Physical Sciences and Mathematics

\section{Publication Details} \\ Bai, Y., Han, C., Chen, X., Yu, H., Zong, X., Li, Z. \& Wang, L. (2015). Boosting the efficiency of quantum dot \\ sensitized solar cells up to $7.11 \%$ through simultaneous engineering of photocathode and photoanode. \\ Nano Energy, 13 609-619.

\section{Authors} \\ Yang Bai, Chao Han, Xinqi Chen, Hua Yu, Xu Zong, Zhen Li, and Lianzhou Wang
}




\section{Boosting the Efficiency of Quantum Dot Sensitized Solar Cells Up to 7.11\% through Simultaneous Engineering of Photocathode and Photoanode}

Yang Bai ${ }^{a}$, Chao Han ${ }^{b}$, Xinqi Chen ${ }^{b}, \mathrm{Hua} \mathrm{Yu}^{a}, \mathrm{Xu}$ Zong $^{c}$, Zhen $\mathrm{Li}^{b, d, *}$, and Lianzhou Wang $^{a, *}$

${ }^{a}$ Nanomaterials Centre, School of Chemical Engineering and Australian Institute for Bioengineering and Nanotechnology, The University of Queensland, Brisbane, QLD, 4072, Australia

${ }^{\mathrm{b}}$ Institute for Superconducting and Electronic Materials, Squires Way, Innovation Campus of University of Wollongong, Wollongong, NSW, 2500, Australia

'State Key Laboratory of Catalysis, Dalian Institute of Chemical Physics, Chinese Academy of Sciences and Dalian Laboratory for Clean Energy, Dalian 116023, China

${ }^{\mathrm{d}}$ School of Radiation Medicine and Radiation Protection, Soochow University, 199 RenAi Road, Suzhou Industrial Park, Suzhou 215123, China

*Corresponding author: L. Wang, l.wang@uq.edu.au; Z. Li, zhenli@suda.edu.cn 


\begin{abstract}
:
We demonstrate a new strategy of boosting the efficiency of quantum dot sensitized solar cells (QDSSCs) by engineering the photocathode and photoanode simultaneously. Nanostructured photocathodes based on non-stoichiometric $\mathrm{Cu}_{2-\mathrm{x}} \mathrm{Se}$ electrocatalysts were developed via a simple and scalable approach for CdS/CdSe QDs co-sensitized solar cells. Compared to $\mathrm{Cu}_{2} \mathrm{~S} \mathrm{CE}$, remarkably improved photovoltaic performance was achieved for QDSSCs with $\mathrm{Cu}_{2-\mathrm{x}} \mathrm{Se}$ CEs. The superior catalytic activity and electrical conductivity of $\mathrm{Cu}_{2-}$ ${ }_{x}$ Se CEs were verified by the electrochemical impedance spectra and Tafel-polarization measurements. To maximize the efficiency enhancement, the photoanodes were optimized by introducing a pillared porous titania composite as the scattering layers for further light harvesting and charge transfer improvement concurrently. The combination of effective $\mathrm{Cu}_{2-}$ ${ }_{x}$ Se electrocatalysts and pillared titania scattering layers contributed to one of the best reported efficiencies of 7.11\% for CdS/CdSe QDs co-sensitized solar cells.
\end{abstract}

Keywords: $\mathrm{Cu}_{2-\mathrm{x}}$ Se photocathode, porous titania photoanode, efficiency, quantum dot sensitized solar cells 


\section{Introduction}

Semiconductor absorbers such as CdS, CdSe and PbS in the forms of quantum dots (QDs) can be tailored to harvest light efficiently due to their tunable band gaps [1, 2] and high absorption coefficient [3]. When they are applied in quantum dot sensitized solar cells (QDSSCs), the extraordinary light harvesting ability coupled with multi-exciton generation (MEG) [4-8] and hot carriers extraction $[9,10]$ via manipulation of size and composition could boost the theoretical power conversion efficiency (PCE) beyond the Shockley-Queisser limit of 32\% [11-16] and lead to the revolution of solar energy conversion. The inorganic nature (robustness against heat and moisture) of QD sensitizers is highly advantageous over the traditional organic dyes [17-20] and newly emerged organic-inorganic lead halide perovskite absorbers [21-24] in terms of performance stability and device reproducibility. Additionally, the low cost and simple fabrication without high vacuum enable QDSSCs to be one of the most promising candidates for next-generation solar cells.

The design of QDSSCs is similar to that of dye-sensitized solar cells (DSSCs). In a typical operation, photoexcited electrons are injected from semiconductor QDs (e.g., CdS, CdSe, $\mathrm{PbS}$ ) into a nanocrystalline photoanode (e.g., $\mathrm{TiO}_{2}$ and $\mathrm{ZnO}$ ), and the electrons flow via external circuit to a photocathode or counter electrode (CE), where the redox electrolyte (for example, polysulfide $\mathrm{S}^{2-} / \mathrm{S}_{\mathrm{n}}{ }^{2-}$ ) are reduced. To date, the potential of QDSSCs has not been well demonstrated and the reported best PCEs for solution stable CdS/CdSe QDSSCs are at the level of $\sim 6 \%$ [25-28]. Previous studies have been concentrated on developing better techniques for the deposition of QD sensitizers [29-36] and the broadening their absorption profiles [28, 37-41] over the past decades. Although the photocurrent density $\left(J_{s c}\right)$ obtained from QDSSCs is comparable to that of DSSCs, the PCE remains much lower than their analogues. This is mainly due to the low open circuit voltage $\left(V_{o c}\right)$ as well as low fill factor $(F F)$. Therefore, in pursuit of high PCE, simultaneous engineering of photocathode and 
photoanode is highly desirable in terms of improving the catalytic activity of CEs whilst reducing the charge recombination at QD/electrolyte interface [14, 26, 30, 42, 43].

Conventional CEs using noble metals including Pt and Au have a serious chemisorption of sulfur species in conjunction with polysulfide $\left(\mathrm{S}^{2-} / \mathrm{S}_{\mathrm{n}}{ }^{2-}\right)$ electrolyte, which is the most efficient and widely used one [44]. This poisoning effect leads to a poor catalytic activity of CE and a high electron transfer resistance at the interface of CE and electrolyte, resulting in low FF. Furthermore, the tardy charge transfer to the oxidized $\mathrm{S}_{\mathrm{n}}{ }^{2-}$ species at CE would induce a high over-potential that reduces the reduction rate and retards the electron flow. Thereby it aggravates the back electron transfer at the photoanode and increases the charge recombination at the semiconductor/electrolyte interface, leading to the loss of $V_{o c}$. To overcome the limitations of the conventional CEs, alternative catalytic materials have been exploited for the reduction of $\mathrm{S}_{\mathrm{n}}{ }^{2-}$ species, for example, $\mathrm{CoS}, \mathrm{CoS}_{2}, \mathrm{CuS}, \mathrm{Cu}_{2} \mathrm{~S}, \mathrm{PbS}, \mathrm{MoS}_{2}$, $\mathrm{Cu}_{2} \mathrm{ZnSnS}_{4}$ and carbon materials [42, 45-54]. Among these candidates, $\mathrm{Cu}_{2} \mathrm{~S}$ CEs that are normally fabricated by exposing the brass sheets to sulfide solution [34, 41] exhibit relatively higher electrocatalytic activity in reducing polysulfide species. However, these $\mathrm{Cu}_{2} \mathrm{~S}$ CEs suffer from continual corrosion when used in conjunction with polysulfide electrolyte, leading to mechanical instability [49]. Moreover, the poor electrical conductivity of $\mathrm{Cu}_{2} \mathrm{~S}$ results in an inefficient charge transfer at the CEs, and a low FF. Although the conductivity could be improved by hybridizing $\mathrm{Cu}_{2} \mathrm{~S}$ with reduced graphene oxide (RGO), the CdS/CdSe co-sensitized solar cells using $\mathrm{Cu}_{2} \mathrm{~S}$ CE are still grappling with 6\% PCE barrier [49, 55]. In view of the similar p-type semiconducting property as $\mathrm{Cu}_{2} \mathrm{~S}$ but significantly higher electrical conductivity [56], $\mathrm{Cu}_{2} \mathrm{Se}$ shows great promise superseding the most common $\mathrm{Cu}_{2} \mathrm{~S}$ catalysts. In addition, its conductivity can be further improved by partial oxidization of exactly stoichiometric $\mathrm{Cu}_{2}$ Se into non-stoichiometric $\mathrm{Cu}_{2-x}$ Se [56]. However, the studies on $\mathrm{Cu}_{2-x} \mathrm{Se}$ are obviously inadequate $[57,58]$. In the reported preparation process, impurities such as $\mathrm{Na}^{+}$, 
$\mathrm{K}^{+}$ions and/or selenide oxide can be easily formed within $\mathrm{Cu}_{2-\mathrm{x}}$ Se films and reproducibility cannot be guaranteed $[57,58]$. The particle size and morphology of $\mathrm{Cu}_{2-\mathrm{x}}$ Se were not well manipulated $[57,58]$. So the fabricated $\mathrm{Cu}_{2-x}$ Se films were far from optimal, and the best PCE obtained from QDSSCs with $\mathrm{Cu}_{1.8}$ Se CE was only 5.01\%, despite large $J_{s c}$ of $20.5 \mathrm{~mA}$ $\mathrm{cm}^{-2}$ [57]. The engineering of photocathode based on well-defined $\mathrm{Cu}_{2-\mathrm{x}}$ Se electrocatalysts featuring high catalytic activity and electrical conductivity is crucial for further improving the efficiency of QDSSCs.

In the meantime, the drawbacks (inefficient light scattering and electron transport) of conventional nanoparticle (NP) photoanodes need to be resolved to maximize the efficiency enhancement in QDSSCs. In order to efficiently transfer electrons and scatter light without compromising QD-loading, our previously developed porous titania nanohybrids (NHs) can be considered as one of the promising photoanode materials [59]. The NHs are prepared by pillaring exfoliated $\mathrm{Ti}_{0.91} \mathrm{O}_{2}$ nanosheets (NSs) with colloidal $\mathrm{TiO}_{2}$ nanoparticles $(7 \sim 9 \mathrm{~nm})$ without deterioration of their fundamental crystal structure [59-61]. In this way, the porosity and surface area of the NHs are significantly enlarged for light absorbers to anchor, and submicrometer-sized crystalline NSs play a key role in increasing the light scattering. In addition, the recombination would be suppressed due to the charge transfer between the guest and host in the layered NH system [59, 62, 63].

Herein, in this study, non-stoichiometric $\mathrm{Cu}_{2-x}$ Se electrocatalysts with well-defined nanostructures (i.e., nanoparticle (NP) and nanowire (NW)) were prepared via facile wetchemical methods in a large scale, and then deposited on FTO substrates using simple doctorblading technique to fabricate $\mathrm{Cu}_{2-\mathrm{x}} \mathrm{Se} \mathrm{NP}$ and NW CEs with high purity and reproducibility for CdS/CdSe QDs co-sensitized solar cells. The QDSSC devices with $\mathrm{Cu}_{2-\mathrm{x}} \mathrm{Se} \mathrm{NP}$ and NW CEs exhibited an encouraging efficiency of $6.50 \%$ and 5.93\%, respectively, which are 
considerably higher than those of devices assembled with both $\mathrm{Au}(2.98 \%)$ and $\mathrm{Cu}_{2} \mathrm{~S}$ (5.55\%) CEs. The superior catalytic activity and electrical conductivity of $\mathrm{Cu}_{2-x} \mathrm{Se} C E s$ were verified by electrochemical impedance spectra (EIS) and Tafel-polarization measurements. To further enhance the efficiency, our previously developed porous titania nanohybrids (NHs) [59] was introduced as the scattering layers of the photoanodes for improving the light harvesting and charge transfer. The simultaneous engineering of photocathode and photoanode boosted the PCE up to 7.11\%, which is among the best reported efficiencies for CdS/CdSe QDs cosensitized solar cells.

\section{Experimental Section}

Synthesis of Cuprous Chalcogenides: $\mathrm{Cu}_{2-\mathrm{x}}$ Se nanoparticle was prepared in pure aqueous solution without any surfactant or other solvent. This guaranteed a clean surface of the final product. $1 \mathrm{mmol}$ of Se powder was reduced by $\mathrm{NaBH}_{4}$ in water under nitrogen flow to form a precursor solution, which will effectively prevent the oxidation of Se precursor. 2 mmol of $\mathrm{CuCl}_{2} \cdot 2 \mathrm{H}_{2} \mathrm{O}$ was dissolved in water forming a blue solution. Once the two solutions were mixed together with precisely controlled molar ratio, the pure $\mathrm{Cu}_{2-\mathrm{x}}$ Se black precipitate was formed immediately. The possible impurity ions $\left(\mathrm{Na}^{+}, \mathrm{BO}^{2-}, \mathrm{OH}^{-}, \mathrm{Cl}^{-}\right)$were removed by washing with water and acetone for several times, and the precipitate was then dried in a vacuum oven. $\mathrm{Cu}_{2} \mathrm{~S}$ NP was synthesized in a similar way as $\mathrm{Cu}_{2-\mathrm{x}} \mathrm{Se} \mathrm{NP}$. Typically, $1 \mathrm{mM}$ $\mathrm{Na}_{2} \mathrm{~S}$ was mixed with $\mathrm{NaBH}_{4}$, and then $2 \mathrm{mM} \mathrm{CuCl}_{2}$ was added into the mixture to form a brown precipitate immediately. The precipitate was washed and dried in a vacuum oven. For the synthesis of $\mathrm{Cu}_{2-\mathrm{x}} \mathrm{Se} \mathrm{NW}, 0.1580 \mathrm{~g}$ of Se powder, $4.800 \mathrm{~g}$ of $\mathrm{NaOH}$, and $20 \mathrm{~mL}$ of distilled water were mixed in a flask with Ar flow and heated to $90{ }^{\circ} \mathrm{C}$ under magnetic stirring. Then $1.5 \mathrm{~mL}$ of $\mathrm{Cu}\left(\mathrm{NO}_{3}\right)_{2}$ aqueous solution $(0.5 \mathrm{M})$ was added into the mixture to form a black suspension immediately. The suspension was transferred into a beaker, and then 
put into an oven at $100{ }^{\circ} \mathrm{C}$ for $18 \mathrm{~h}$ until the water was completely evaporated. The black $\mathrm{Cu}_{2-}$ ${ }_{x}$ Se NW precipitate was washed with water and then dried in a vacuum.

Electrodes Preparation: The resultant $\mathrm{Cu}_{2-\mathrm{x}} \mathrm{Se}$ and $\mathrm{Cu}_{2} \mathrm{~S}$ powders were prepared into pastes according to our previous work with some modifications [59]. The CE pastes were deposited on cleaned FTO substrates by doctor blade technique. The formed films were then annealed at $350{ }^{\circ} \mathrm{C}$ for $30 \mathrm{~min}$ in $\mathrm{Ar}$ atmosphere for $30 \mathrm{~min}$ to remove the binder and enhance the contact between films and substrates. Au CEs were prepared by sputtering with a thickness of ca. $50 \mathrm{~nm}$ (obtained from the calibration curve of sputtering). Photoanode were prepared by casting $\mathrm{TiO}_{2}$ pastes on FTO substrates using successive doctor blade technique. The $\mathrm{TiO}_{2}$ film is composed of a transparent layer (18NR-T Dyesol paste) and a light-scattering layer (WER2-O Dyesol paste or titania nanohybrids paste [59]). The synthesis of titania nanohybrids can be found elsewhere [59]. The photoanode films were gradually heated at $100{ }^{\circ} \mathrm{C}$ for $15 \mathrm{~min}$ and $500{ }^{\circ} \mathrm{C}$ for $30 \mathrm{~min}$, respectively [64].

Fabrication of QDSSCs: CdS and CdSe QDs were deposited throughout the resultant $\mathrm{TiO}_{2}$ films by the successive ionic layer adsorption and reaction (SILAR) and chemical bath deposition (CBD) methods, respectively [34]. Typically $\mathrm{TiO}_{2}$ electrodes were first immersed in a solution containing $0.1 \mathrm{M} \mathrm{Cd}\left(\mathrm{NO}_{3}\right)_{2} \bullet 4 \mathrm{H}_{2} \mathrm{O}$ in ethanol for $1 \mathrm{~min}$, which allows $\mathrm{Cd}^{2+}$ to absorb on $\mathrm{TiO}_{2}$. The electrodes were then rinsed with ethanol to remove the excess $\mathrm{Cd}^{2+}$ and dried with gentle $\mathrm{N}_{2}$ stream. Successively, the dried electrodes were dipped into $0.1 \mathrm{M}$ $\mathrm{Na}_{2} \mathrm{~S} \cdot 9 \mathrm{H}_{2} \mathrm{O}$ solution containing water and methanol $(1: 1, \mathrm{v} / \mathrm{v})$ for another $1 \mathrm{~min}$, where the $\mathrm{S}^{2-}$ will react with the pre-adsorbed $\mathrm{Cd}^{2+}$ to form CdS. Then the resultant electrodes were rinsed in methanol and dried again with $\mathrm{N}_{2}$ flow. This procedure was referred as one SILAR cycle. Five cycles were performed to achieve a suitable CdS loading on $\mathrm{TiO}_{2}$ films. Afterwards, CdSe was loaded on the CdS-sensitized $\mathrm{TiO}_{2}$ electrodes using the CBD method $[34,35,65,66]$ with some modifications. $0.1 \mathrm{M} \mathrm{Na}_{2} \mathrm{SeSO}_{3}$ solution was prepared by 
refluxing $0.1 \mathrm{M}$ Se powder with $0.25 \mathrm{M} \mathrm{Na}_{2} \mathrm{SO}_{3}$ at ca. $80{ }^{\circ} \mathrm{C}$ for several hours. Then an aqueous precursor solution was obtained by mixing $0.1 \mathrm{M} \mathrm{CdSO}_{4}, 0.2 \mathrm{M} \mathrm{N}\left(\mathrm{CH}_{2} \mathrm{COONa}\right)_{3}$, and $0.1 \mathrm{M} \mathrm{Na}_{2} \mathrm{SeSO}_{3}$ together with a volume ratio of 1:1:1. The CdS-sensitized $\mathrm{TiO}_{2}$ electrodes were immersed into the precursor solution for CdSe deposition in dark at room temperature for $6 \mathrm{~h}$. After QD deposition, a ZnS passivation layer was coated on the $\mathrm{CdS} / \mathrm{CdSe} / \mathrm{TiO}_{2}$ electrodes. Three SILAR cycles were conducted for $\mathrm{ZnS}$ deposition with 0.1 $\mathrm{M}$ zinc nitrate as $\mathrm{Zn}^{2+}$ source and $0.1 \mathrm{M}$ sodium sulfide aqueous solutions as $\mathrm{S}^{2-}$ source. QDSSC devices were fabricated by sandwiching QD-sensitized $\mathrm{TiO}_{2}$ film electrode and CEs $\left(\mathrm{Cu}_{2-\mathrm{x}} \mathrm{Se}, \mathrm{Cu}_{2} \mathrm{~S}\right.$, and $\left.\mathrm{Au}\right)$ with a binder clip separated by a $60 \mu \mathrm{m}$ thick spacer. A metal mask $\left(0.16 \mathrm{~cm}^{2}\right)$ was clipped on the photoanode side to define the active area during testing. The aqueous polysulfide electrolyte comprised of $2 \mathrm{M} \mathrm{Na}_{2} \mathrm{~S}, 2 \mathrm{M} \mathrm{S}$, and $0.2 \mathrm{M} \mathrm{KCl}$. The symmetric dummy cells were assembled by two identical CEs, clipping the same polysulfide electrolyte for electrochemical impendence spectroscopy (EIS) and Tafel polarization measurements. The active area of the dummy cells was defined as $0.64 \mathrm{~cm}^{2}$ [67]. Characterization and Measurements: X-ray diffraction (XRD) patterns for all samples were recorded by using $\mathrm{Cu} \mathrm{K \alpha}(\lambda=0.15406 \mathrm{~nm})$ radiation at $40 \mathrm{kV}$ and $25 \mathrm{~mA}$ with a positionsensitive detector. X-ray photoelectron spectroscopy (XPS) and inductively coupled plasma atomic emission spectroscopy (ICP-AES) were used to characterize the chemical composition of the samples. The morphology of the powder and electrode samples was examined by scanning electron microscopy (SEM, JEOL JMS7500-FA and JEOL 7001) and transmission electron microscope (TEM, JEOL 2011). Energy dispersive X-ray spectroscopy (EDS) measurements were taken on a JEOL 6610 SEM for QD-sensitized $\mathrm{TiO}_{2}$ film. The photocurrent-voltage $(J-V)$ tests of QDSSCs were performed under simulated AM 1.5 solar spectrum irradiation. $J$ - $V$ curves were recorded by a Keithley model 2420 digital source meter. The incident photon-to-current conversion efficiency (IPCE) plotted as a function of the 
excitation wavelength was obtained by using a Newport 1918-c power meter under irradiation of a 300 W Oriel xenon light source with an Oriel Cornerstone 260 1/4 m monochromator in direct-current mode. The EIS measurements were conducted in the dark using Solartron 1260 Frequency Response Analyzer in combination with a Solartron 1480 Potentiostat [67]. The Tafel-polarization measurements were recorded by an Electrochemical Workstation (CHI660d) [67].

\section{Results and Discussion}

$\mathrm{Cu}_{2-\mathrm{x}} \mathrm{Se}$ NPs and NWs were prepared by environmentally friendly and surfactant-free aqueous approaches, and were comprehensively characterized. Figure 1 shows their scanning electron microscopy (SEM) and transmission electron microscopy (TEM) images, in which $\mathrm{Cu}_{2-\mathrm{x}} \mathrm{Se} \mathrm{NPs}$ have a uniform size with a narrow size distribution $(\mathrm{D}=13.6 \pm 2.9 \mathrm{~nm}$ (Figure 1a, b), and NWs are in diameters of 100-300 nm and lengths up to tens of micrometers (Figure 1c, d). 

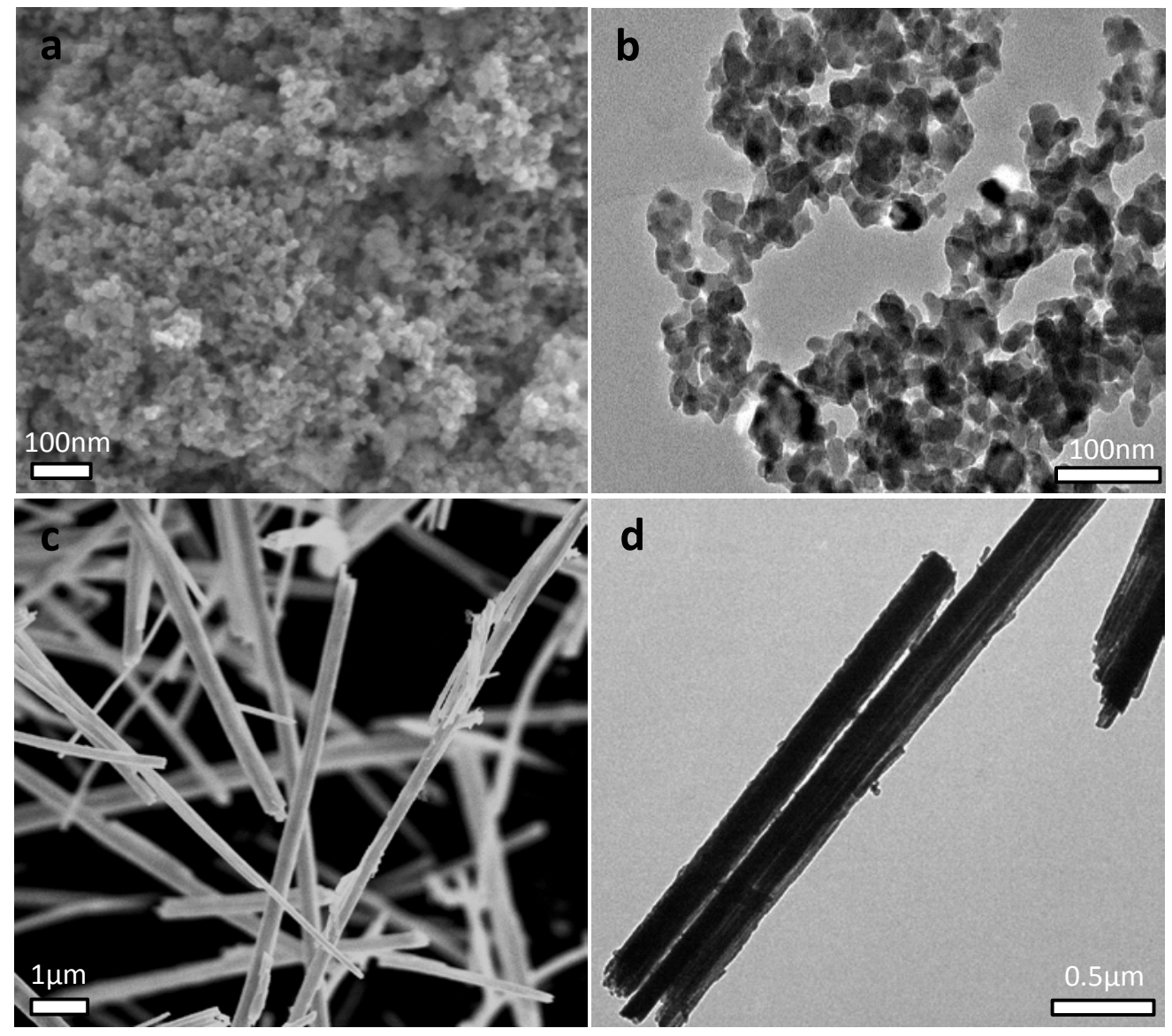

Figure 1. SEM and TEM images of (a-b) as-prepared $\mathrm{Cu}_{2-\mathrm{x}} \mathrm{Se} \mathrm{NPs}$; and (c-d) $\mathrm{Cu}_{2-\mathrm{x}} \mathrm{Se} \mathrm{NWs}$. The crystal structures of the two samples were investigated by XRD measurement. As indicated in the XRD patterns (Figure 2), both the NP and NW samples showed the characteristic peaks of cubic $\mathrm{Cu}_{2-\mathrm{x}} \mathrm{Se}$ (JCPDS 06-0680) [68]. In order to investigate their surface oxidation states and chemical composition, X-ray photoelectron spectroscopy (XPS) analysis was conducted for all the samples. Only the peaks of $\mathrm{C}, \mathrm{Cu}, \mathrm{O}$, and Se were observed in the XPS surveys (Figure S1), and no evident impurities (such as $\mathrm{Na}, \mathrm{B}, \mathrm{Cl}$ ) were detected in the products. 


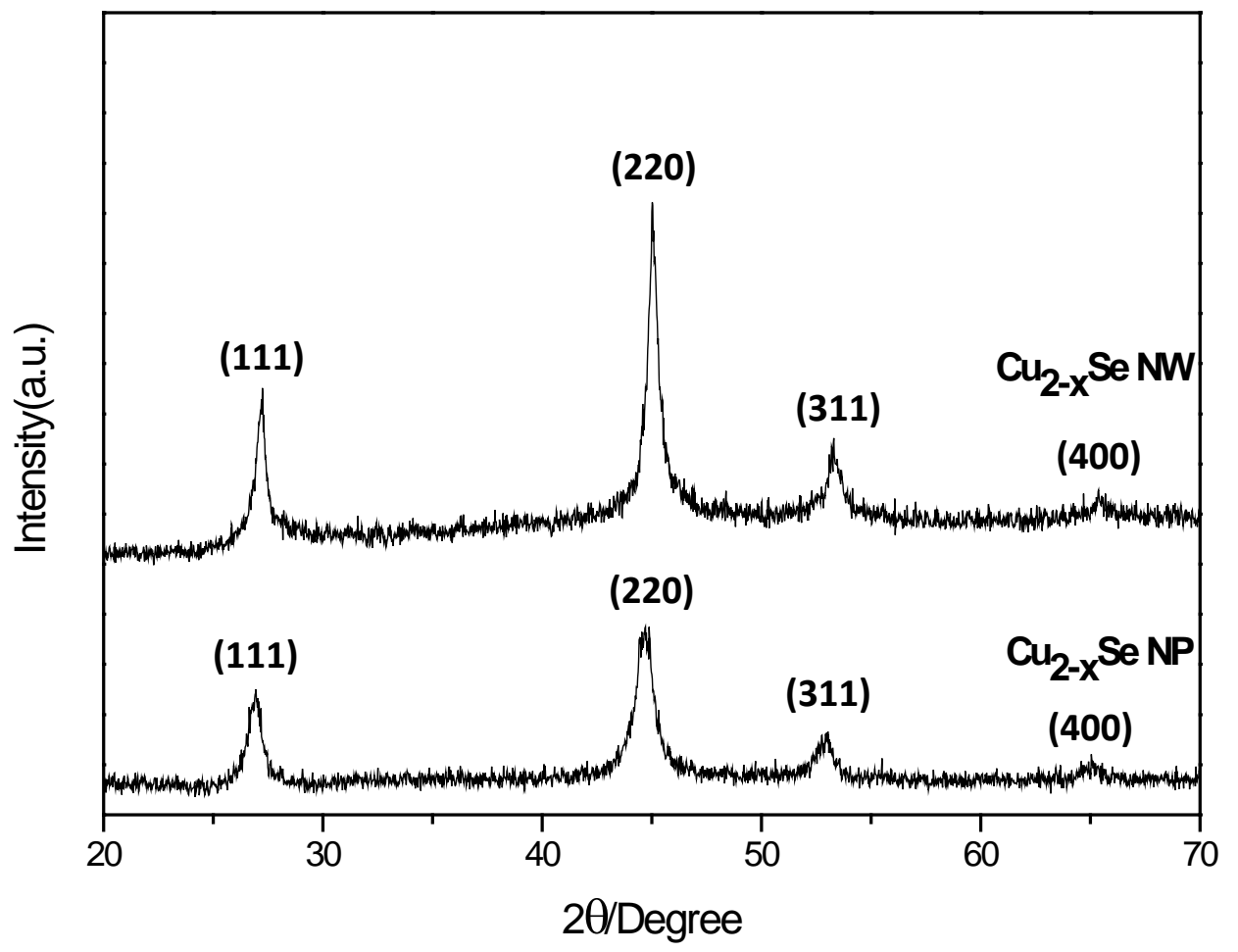

Figure 2. XRD patterns of as-prepared $\mathrm{Cu}_{2-\mathrm{x}} \mathrm{Se} \mathrm{NPs}$ and $\mathrm{Cu}_{2-\mathrm{x}} \mathrm{Se} \mathrm{NWs}$.

Figure 3 presents the high resolution XPS spectra of $\mathrm{Cu} 2 \mathrm{p}$ and $\mathrm{Se} 3 \mathrm{~d}$ from $\mathrm{Cu}_{2-\mathrm{x}} \mathrm{Se}$ NPs and NWs, respectively. The XPS spectra of Cu 2p orbit (Figure 3a, c) revealed two main peaks corresponding to $\mathrm{Cu} 2 \mathrm{p}_{3 / 2}$ and $\mathrm{Cu} 2 \mathrm{p}_{1 / 2}$, and proved the presence of both $\mathrm{Cu}^{2+}$ and $\mathrm{Cu}^{+}$in both $\mathrm{Cu}_{2-\mathrm{x}} \mathrm{Se} \mathrm{NPs}$ and NWs. As indicated in Figure 3a, the binding energy of $\mathrm{Cu} 2 \mathrm{p}_{3 / 2}$ from $\mathrm{Cu}_{2-}$ ${ }_{x}$ Se NPs can be fitted into two peaks loaded at $931.9 \mathrm{eV}\left(\mathrm{Cu}^{+}, 81.43 \%\right)$ and $933.8 \mathrm{eV}\left(\mathrm{Cu}^{2+}\right.$, 18.57\%). The Se 3d appearing at the binding energy of $54.6 \mathrm{eV}$, was attributed to $\mathrm{Se}^{2-}$ in $\mathrm{Cu}_{2-}$ ${ }_{x}$ Se NPs, demonstrating the absence of other selenium species and high purity of the sample. The Cu:Se ratio determined from the XPS quantitative analysis was ca. 1.67, which is close to the value of 1.73 from the ICP analysis. In the case of $\mathrm{Cu}_{2-\mathrm{x}} \mathrm{Se}$ NWs, the binding energy of $\mathrm{Cu} 2 \mathrm{p}_{3 / 2}$ was deconvoluted into two peaks centred at $931.5 \mathrm{eV}\left(\mathrm{Cu}^{+}, 80.6 \%\right)$ and $933.9 \mathrm{eV}$ $\left(\mathrm{Cu}^{2+}, 19.4 \%\right)$. Combining with the XPS spectrum of Se 3d (Figure 3d) from Se ${ }^{2-}$, the ratio of $\mathrm{Cu}$ to Se in $\mathrm{Cu}_{2-\mathrm{x}} \mathrm{Se} \mathrm{NWs}$ was calculated to be 1.61 , which is in good agreement with the ICP result of 1.65 . 

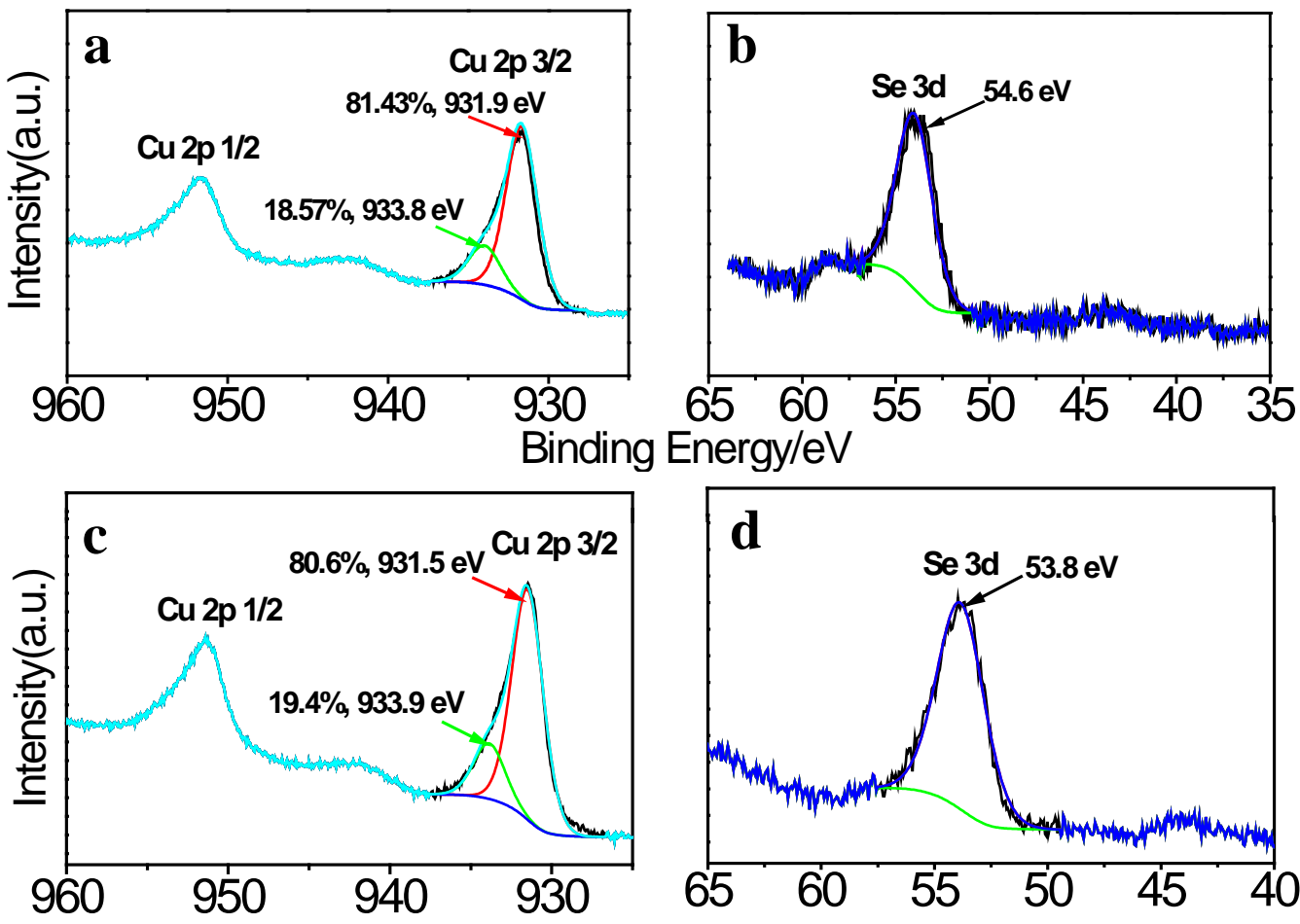

Binding Energy/eV

Figure 3. High resolution XPS spectra of (a, c) Cu 2p and (b, d) Se 3d from $\mathrm{Cu}_{2-x} \mathrm{Se}$ NPs, and $\mathrm{Cu}_{2-\mathrm{x}} \mathrm{Se} \mathrm{NWs}$, respectively.

$\mathrm{Cu}_{2} \mathrm{~S}$ NPs were also prepared in a similar way as $\mathrm{Cu}_{2-\mathrm{x}} \mathrm{Se}$ counterparts for comparison. The morphology of the as-prepared $\mathrm{Cu}_{2} \mathrm{~S}$ sample was presented in Figure S2. The uniform nanoparticles possessed a size distribution of $12.8 \pm 3.1 \mathrm{~nm}$. The XRD pattern (Figure S3) showed that all the diffraction peaks of the obtained brown precipitates can be well indexed to the pure $\mathrm{Cu}_{2} \mathrm{~S}$ (JCPDS 46-1195). The XPS analysis (Figure S4) was performed to determine the chemical composition of the $\mathrm{Cu}_{2} \mathrm{~S}$ sample. As shown in Figure $\mathrm{S} 4 \mathrm{~b}$, the peak at $931.9 \mathrm{eV}$ which is referred to $\mathrm{Cu} 2 \mathrm{p}_{3 / 2}$, indicated that $\mathrm{Cu}$ ions were in the form of $\mathrm{Cu}$ (I) state. The absence of typical satellite peak of $\mathrm{Cu}^{2+}$ at around $942 \mathrm{eV}$ demonstrated the high purity of $\mathrm{Cu}_{2} \mathrm{~S}$ NPs. The $\mathrm{S} 2 \mathrm{p}$ XPS spectrum (Figure $\mathrm{S} 4 \mathrm{c}$ ) was ascribed to $\mathrm{S}^{2-}$ coordinated to $\mathrm{Cu}^{+}$in $\mathrm{Cu}_{2} \mathrm{~S}$ NPs. 

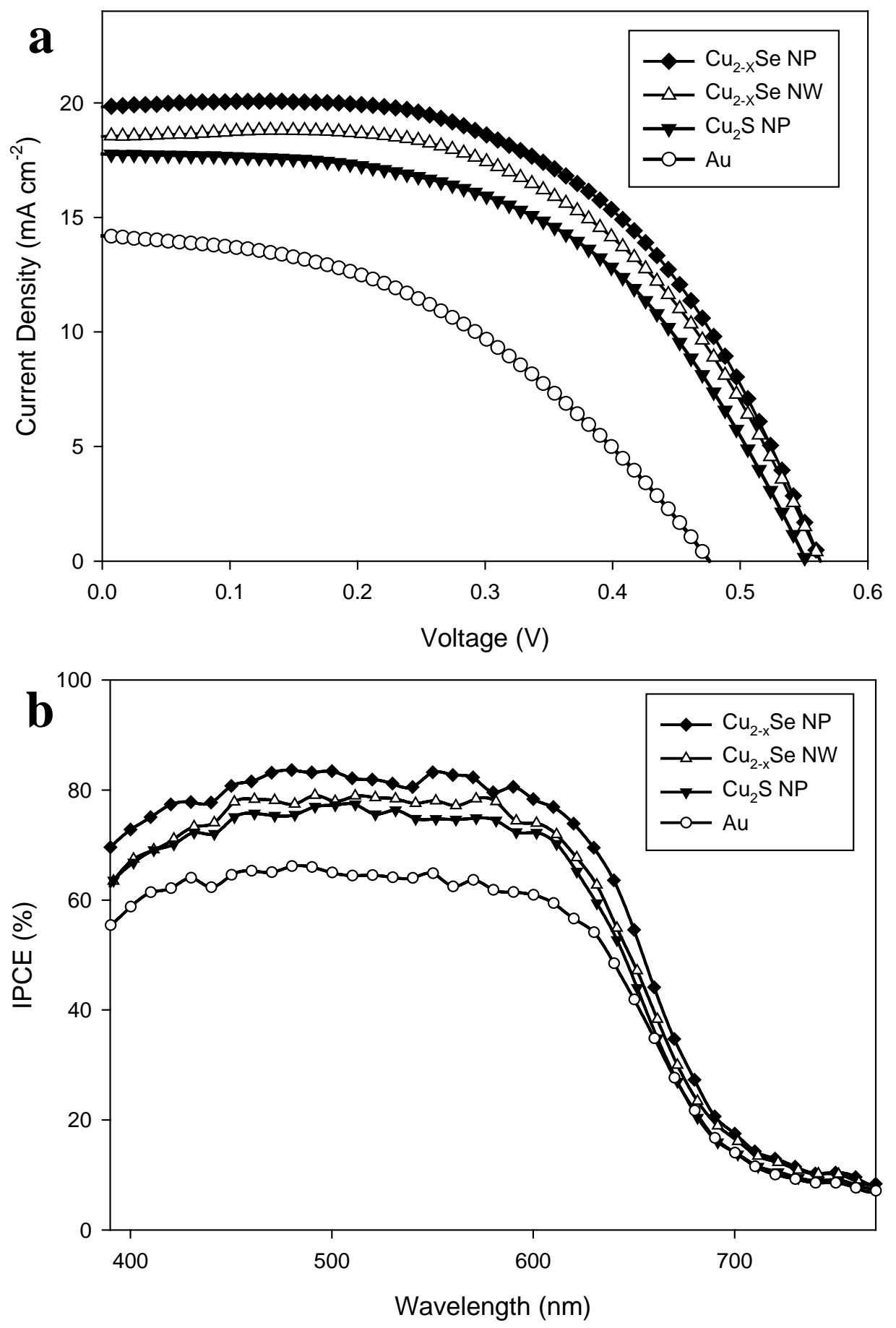

Figure 4. (a) Photocurrent density-voltage curves and (b) IPCE spectra of QDSSCs with different CEs measured under AM1.5 illumination $\left(100 \mathrm{~mW} \mathrm{~cm}^{-2}\right)$

Table 1. EIS parameters ${ }^{\mathrm{a})}\left(R_{s}, R_{c t}, Z_{w}\right)$ of the dummy cells assembled with two identical CEs for each sample, and photovoltaic performance parameters ${ }^{\text {b) }}\left(J_{s c}, V_{o c}, F F, \eta\right)$ of four different CE samples in QDSSCs.

\begin{tabular}{lcllllll}
\hline Samples & $\begin{array}{c}R_{\mathrm{s}} \\
(\Omega)\end{array}$ & $R_{c t}(\Omega)$ & $Z_{w}(\Omega)$ & $J_{s c}\left(\mathrm{~mA} \mathrm{~cm}^{-2}\right)$ & $V_{o c}(\mathrm{mV})$ & $F F(\%)$ & $\eta(\%)$ \\
& & & & & & \\
\hline
\end{tabular}




\begin{tabular}{lccccccc}
\hline $\mathrm{Au}$ & 14.6 & 38.43 & 77.78 & 14.25 & 471 & 44.4 & 2.98 \\
$\mathrm{Cu}_{2} \mathrm{~S}-\mathrm{NP}$ & 17.8 & 1.48 & 4.96 & 17.85 & 551 & 56.4 & 5.55 \\
$\mathrm{Cu}_{2-\mathrm{S}} \mathrm{Se}-\mathrm{NP}$ & 13.1 & 0.58 & 3.12 & 19.76 & 563 & 58.4 & 6.50 \\
$\mathrm{Cu}_{2-\mathrm{x}} \mathrm{Se}-\mathrm{NW}$ & 12.6 & 0.84 & 5.2 & 18.36 & 561 & 57.6 & 5.93 \\
\hline
\end{tabular}

${ }^{a} R_{s}$ : series resistance, $R_{c t}$ : charge-transfer resistance at the CE/electrolyte interface, $Z_{w}$ : Warburg impedance.

b) $J_{s c}$ : short-circuit current density, $V_{o c}$ : open-circuit voltage, FF: fill factor, $\eta$ : energy conversion efficiency; the average value of each data was obtained by testing at least 6 cells.

In order to investigate the catalytic property of $\mathrm{Cu}_{2-x}$ Se samples, $\mathrm{CE}$ films were prepared by depositing $\mathrm{Cu}_{2-\mathrm{x}} \mathrm{Se} \mathrm{NP}$ or $\mathrm{Cu}_{2-\mathrm{x}}$ Se NW paste on FTO substrates using the doctor-blading method (refer to the Experimental section for more details). Prior to any testing, XPS analysis was conducted again on the resultant $\mathrm{Cu}_{2-x}$ Se films after annealing under Ar flow. Figure S5 showed the XPS spectra of $\mathrm{Cu} 2 \mathrm{p}$ from the annealed $\mathrm{Cu}_{2-\mathrm{x}}$ Se NP film as well as $\mathrm{Cu}_{2-\mathrm{x}} \mathrm{Se} \mathrm{NW}$ film. No significant change was detected compared to the original samples, which implied the good stability of $\mathrm{Cu}_{2-x} \mathrm{Se}$. For comparison, $\mathrm{Cu}_{2} \mathrm{~S}$ CE film was fabricated and treated in a similar way as those of the $\mathrm{Cu}_{2-x}$ Se CE films.

$\mathrm{Cu}_{2-\mathrm{x}} \mathrm{Se} \mathrm{CEs}$ were then assembled with $\mathrm{TiO}_{2}$ photoanodes to construct QDSSC devices containing aqueous polysulfide electrolyte (with $\mathrm{Cu}_{2} \mathrm{~S}$ and $\mathrm{Au}$ as the reference $\mathrm{CEs}$ ) and the photovoltaic properties of the QDSSCs were analyzed to evaluate the electrocatalytic property of the CEs. Standard $\mathrm{TiO}_{2}$ photoanode (Figure S6) was composed of a bottom transparent layer (18NR-T Dyesol paste) and a top scattering layer (WER2-O Dyesol paste) and was abbreviated as $\mathrm{WD}^{-\mathrm{TiO}_{2}}$. CdS and CdSe QDs were successfully deposited through the $\mathrm{TiO}_{2}$ films sequentially by combining the SILAR and CBD processes. Compared to pristine $\mathrm{TiO}_{2}$, the absorption of CdS/CdSe-sensitized $\mathrm{TiO}_{2}$ film in Figure S7 showed red shift with absorption onset below $700 \mathrm{~nm}$. The color changed from white to black-brown with QDloading as shown in the inset of Figure S7. After the deposition of CdS/CdSe QDs, a thin ZnS passivation layer was coated onto the sensitized electrode by three SILAR deposition cycles. The wide band-gap ZnS layer plays an important role in reducing the internal recombination 
at QDs as well as the charge recombination at the QD/electrolyte and $\mathrm{TiO}_{2} /$ electrolyte interfaces before charge injection and thus improving the efficiency [37, 69, 70]. Figure 4a shows the photocurrent density-voltage $(J-V)$ characteristics of these QDSSCs under the standard simulated AM 1.5 illumination with an intensity of $100 \mathrm{~mW} \mathrm{~cm}^{-2}$ in the presence of a mask. At least 6 cells were constructed and evaluated in parallel for the performance measurements. The average photovoltaic performance parameters are summarized in Table 1. The reference cell fabricated with Au CE exhibited a short-current density $\left(J_{s c}\right)$ of $14.25 \mathrm{~mA}$ $\mathrm{cm}^{-2}$, an open-circuit voltage $\left(V_{o c}\right)$ of $471 \mathrm{mV}$, and a fill factor $(F F)$ of $44.4 \%$, yielding an overall power conversion efficiency $(\eta)$ of $2.98 \%$, which is comparable to the previous results reported [12, 42]. Employing $\mathrm{Cu}_{2} \mathrm{~S}$ NP CEs in QDSSCs resulted in a higher efficiency of 5.55\%, owing to the significant improvement in $J_{s c}\left(17.85 \mathrm{~mA} \mathrm{~cm}^{-2}\right), V_{o c}(551 \mathrm{mV})$, as well as FF (54.3\%). These performance parameters are also comparable to those of the previously reported QDSSC devices consisting of $\mathrm{Cu}_{2} \mathrm{~S}$ on brass [34, 71] or $\mathrm{Cu}_{2} \mathrm{~S} / \mathrm{RGO}$ as CEs [25, 49]. Despite that $\mathrm{Cu}_{2} \mathrm{~S}$ has widely been recognized as the most effective CE catalysts for QDSSCs, the stagnation in the performance of QDSSCs incorporating $\mathrm{Cu}_{2} \mathrm{~S}$ CEs has been recently driving the exploration of novel CE catalysts with even higher catalytic activity for the reduction of $\mathrm{S}_{\mathrm{n}}{ }^{2-}$. Encouragingly, QDSSCs fabricated with both $\mathrm{Cu}_{2-\mathrm{x}} \mathrm{Se} \mathrm{NW}$ and NP CEs presented significantly improved efficiency of 5.93\% and 6.50\%, respectively. The efficiency enhancement was attributed to the augment in all photovoltaic parameters, especially in $J_{s c}$ and FF. Compared to the cell with $\mathrm{Cu}_{2} \mathrm{~S}$ CEs, QDSSCs incorporating $\mathrm{Cu}_{2-\mathrm{x}} \mathrm{Se} \mathrm{NW}$ and NP CEs exhibited a higher $J_{s c}$ of 18.36 and $19.76 \mathrm{~mA} \mathrm{~cm}^{-2}$, respectively, indicating the fast reduction of $\mathrm{S}_{\mathrm{n}}{ }^{2-}$ to $\mathrm{nS}^{2-}$. In addition, the remarkable increase in FF of QDSSCs with $\mathrm{Cu}_{2-\mathrm{x}} \mathrm{Se}$ CEs is ascribed to the higher electrical conductivity.

The photocurrent response to incident light for QDSSCs incorporating various CEs was analyzed by IPCE as shown in Figure 4b. The overall photocurrent response was consistent 
with the absorption features and the photocurrent onset starts at around $700 \mathrm{~nm}$ for $\mathrm{TiO}_{2} / \mathrm{CdS} / \mathrm{CdSe}$-based QDSSCs. The higher IPCE in the short wavelength range is due to the strong absorption of CdS, whereas CdSe harvests light efficiently in the long wavelength range $[28,72]$. Compared to QDSSCs with Au CE, the IPCE spectrum of QDSSCs employing $\mathrm{Cu}_{2} \mathrm{~S} \mathrm{CE}$ was higher over the entire wavelength region; however, it was lower than those of QDSSCs fabricated with $\mathrm{Cu}_{2-\mathrm{x}}$ Se CEs. This result is in good accordance with the observed $J_{s c}$ as listed in Table 1. The significant IPCE enhancement of QDSSCs fabricated with $\mathrm{Cu}_{2-x}$ Se CEs further indicated that $\mathrm{Cu}_{2-\mathrm{x}}$ Se possesses super electrocatalytic activity in reducing $\mathrm{S}_{\mathrm{n}}{ }^{2-}$ to $\mathrm{nS}^{2-}$, and great potential in superseding the most common $\mathrm{Cu}_{2} \mathrm{~S}$ as the more effective CE catalysts for high efficiency QDSSCs.

To interpret the catalytic behaviors of these CEs related to photovoltaic performances, electrochemical impedance spectra measurements were first carried out using dummy cells assembled with two identical electrodes (CE/polysulfide electrolyte/CE). Nyquist plots of dummy cells were presented in Figure 5a illustrating the impedance characteristics of different CEs. The impedance characteristics of CEs in polysulfide electrolyte are determined by several operational circuit elements such as series resistance $\left(R_{s}\right)$, charge transfer resistance $\left(R_{c t}\right)$, and Warburg diffusion impedance $\left(Z_{w}\right)$. The bulk resistance of CE materials, FTO substrate resistance, and contact resistance together comprise series resistance $\left(R_{s}\right)$. The Warburg impedance $\left(Z_{w}\right)$ describes the polysulfide electrolyte diffusion and a series resistance. The charge-transfer resistance $\left(R_{c t}\right)$ is a measure of electrocatalytic activity toward 

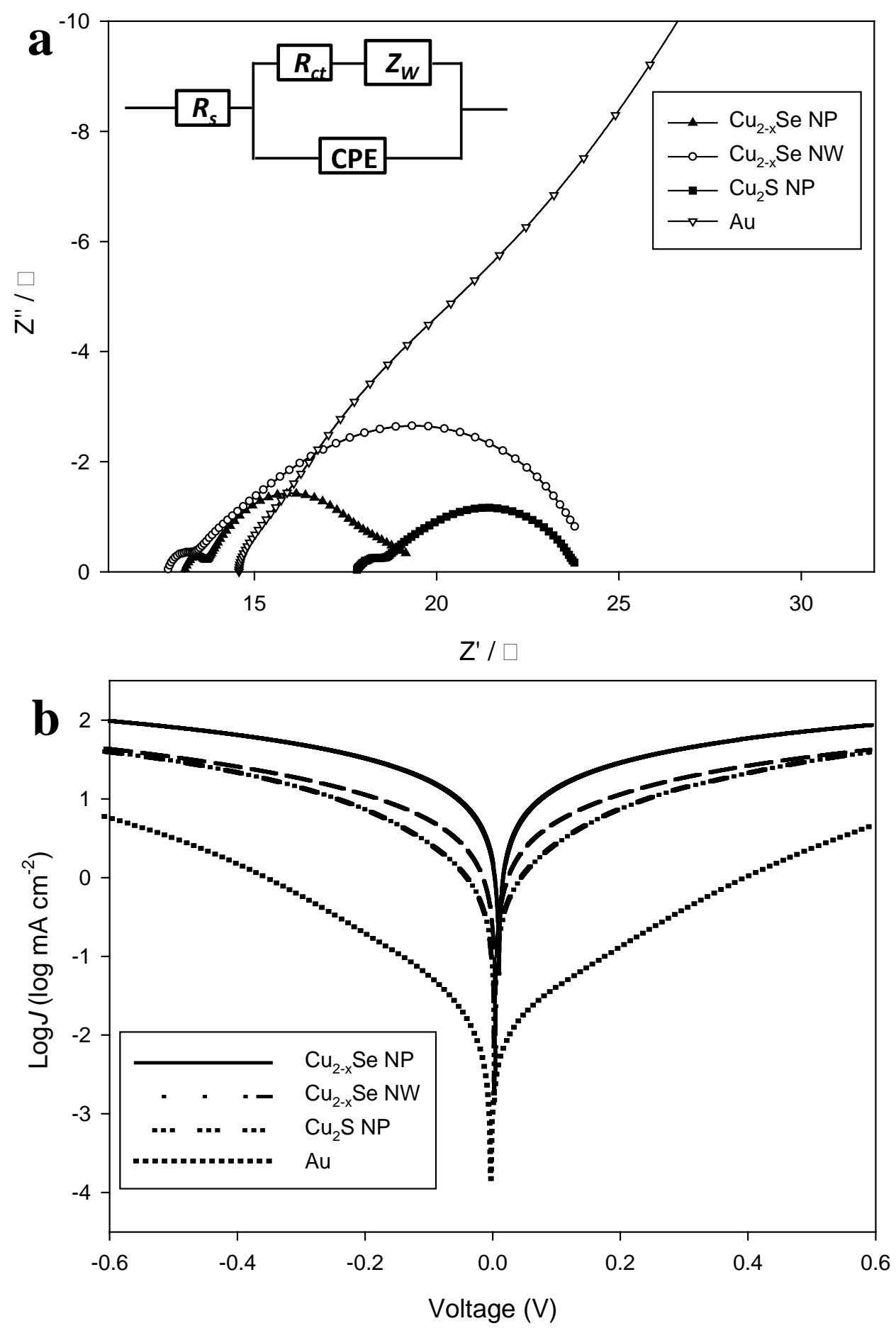

Figure 5. (a) Nyquist plots of the symmetrical dummy cells fabricated with various CEs, the inset shows the equivalent circuit; (b) Tafel polarization curves of different dummy cells used for EIS measurement.

the reduction of polysulfide species $\mathrm{S}_{\mathrm{n}}{ }^{2-}$, which is the key step of the catalytic process [49, 73]. Thereby, $R_{c t}$ is considered as the pivotal parameter determining the catalytic capability of CE catalysts [42, 74, 75]. According to the equivalent circuit shown in the inset of Figure 5a, 
the high-frequency intercept on the real axis represents the series resistance $\left(R_{s}\right)$. The left arc in the middle-frequency region is ascribed to the charge transfer resistance $\left(R_{c t}\right)$, which corresponds to the charge transfer at the interface of CE/electrolyte and changes inversely with the catalytic activity of different CEs. The Warburg diffusion impedance $\left(Z_{w}\right)$ arises from mass transport limitations due to the diffusion of the $\mathrm{S}_{\mathrm{n}}{ }^{2-} / \mathrm{nS}^{2-}$ couple within the electrolyte [75-77], and can be obtained by fitting the right-hand arc in the low-frequency range. The well fitted Nyquist plots can be found in Figure S8. All the parameters determined from the fitted Nyquist plots in the Z-view software were summarized in Table 1. As expected, $\mathrm{Cu}_{2} \mathrm{~S}$ CE possessed a lower charge transfer resistance $\left(R_{c t}\right)$ of $1.48 \Omega$ in comparison with Au CE (38.43 $\Omega$ ). Encouragingly, $R_{c t}$ of $\mathrm{Cu}_{2-\mathrm{x}} \mathrm{Se}$ NP CE $(0.58 \Omega)$ and NW CE (0.84 $\left.\Omega\right)$ were much less than that of $\mathrm{Cu}_{2} \mathrm{~S} \mathrm{CE}$, which indicates the superior catalytic capability of $\mathrm{Cu}_{2-}$ ${ }_{\mathrm{x}}$ Se for the reduction of $\mathrm{S}_{\mathrm{n}}{ }^{2-}$. This is consistent with the increased $J_{s c}$ and $V_{o c}$ displayed in Table 1. Compared to Au and $\mathrm{Cu}_{2} \mathrm{~S}$ CEs, $\mathrm{Cu}_{2-x} \mathrm{Se}$ NP and NW CEs showed a smaller series resistance $\left(R_{s}\right)$ of 13.1 and $12.6 \Omega$, respectively. This reveals higher electrical conductivity of $\mathrm{Cu}_{2-\mathrm{x}} \mathrm{Se}$ and coincides well with previous study [13]. In addition, $\mathrm{Cu}_{2-\mathrm{x}} \mathrm{Se}$ NP CE delivered the smallest Warburg impedance $\left(Z_{w}\right)$ of $3.12 \Omega$, whilst Au CE has the highest $Z_{w}$ of $77.78 \Omega$, implying the much more efficient diffusion of polysulfide electrolyte at the interface of $\mathrm{Cu}_{2-}$ ${ }_{x}$ Se CE/electrolyte. The decreased $Z_{w}$ as well as $R_{s}[78]$ lead to remarkably increased fill factor $(F F)$ of QDSSCs fabricated with $\mathrm{Cu}_{2-\mathrm{x}}$ Se CEs. Therefore, all these parameters jointly contribute to the excellent electrocatalytic activity of $\mathrm{Cu}_{2-\mathrm{x}} \mathrm{Se} \mathrm{CEs}$, and enhanced photovoltaic performance of QDSSCs is highly foreseeable.

Tafel polarization measurements were also conducted with the dummy cells used in EIS experiments to further investigate the electrocatalytic characteristics of various CEs in catalyzing the reduction of $\mathrm{S}_{\mathrm{n}}{ }^{2-}$. Figure $5 \mathrm{~b}$ shows the logarithmic current density $(\log \mathrm{J})$ as a function of the voltage $(\mathrm{U})$ for the oxidation/reduction of $\mathrm{S}_{\mathrm{n}}{ }^{2-}$ to $\mathrm{nS}^{2-}$. The slopes for the 
anodic and cathodic branches are in the order of $\mathrm{Cu}_{2-\mathrm{x}} \mathrm{Se} \mathrm{NP}>\mathrm{Cu}_{2-\mathrm{x}} \mathrm{Se} \mathrm{NW}>\mathrm{Cu}_{2} \mathrm{~S} \mathrm{NP}>\mathrm{Au}$. According to Eq. 1 ( $R$ is the gas constant, $T$ is the temperature, $F$ is the Faraday's constant, and $n$ is the number of electrons involved in the electrochemical reduction of polysulfide at the electrode), the larger slopes for $\mathrm{Cu}_{2-\mathrm{x}} \mathrm{Se}$ electrodes represent the larger exchange current density $\left(J_{0}\right)[42,75,79,80]$, which is in good agreement with the EIS results.

$$
J_{0}=R T / n F R_{c t}
$$

Eq. 1

Furthermore, the limiting current density $J_{\lim }$ determined by the diffusion of ionic carriers between the two electrodes, is directly proportional to the diffusion coefficient $(D)$ of the $\mathrm{S}_{\mathrm{n}}{ }^{2-}$ $/ \mathrm{nS}^{2-}$ redox couple [79]. As shown in Figure 5b, the value of $J_{\text {lim }}$ as well as $D$ increases in the same order of $\mathrm{Cu}_{2-\mathrm{x}} \mathrm{Se} \mathrm{NP}>\mathrm{Cu}_{2-\mathrm{x}} \mathrm{Se} \mathrm{NW}>\mathrm{Cu}_{2} \mathrm{~S} \mathrm{NP}>\mathrm{Au}$, which is consistent with the EIS analysis on $Z_{w}$ [81]. The diffusion coefficient $D$ can be obtained by Eq. 2 , where $l$ is the spacer thickness, $n$ is the number of electrons involved in the reduction of $\mathrm{S}_{\mathrm{n}}{ }^{2-}$ at the electrode, $F$ is the Faraday constant, and $C$ is the $\mathrm{S}_{\mathrm{n}}{ }^{2-}$ concentration.

$$
D=J_{\text {lim }} l / 2 n F C
$$

To examine the electrochemical stability of the $\mathrm{Cu}_{2-x}$ Se CEs, EIS measurements over time were carried out for the dummy cells fabricated with $\mathrm{Cu}_{2-x}$ Se NP CE. Figure S9 shows the Nyquist plots of the fresh and aged dummy cells over time. Clearly, $\mathrm{Cu}_{2-x} \mathrm{Se}$ NP CEs displayed an almost negligible change within 7 days in the Nyquist plots. As aging time goes on, the Warburg diffusion impedance $\left(Z_{w}\right)$ slightly increased. This may be caused by the minor electrolyte leakage due to the limited sealing technique. However, the CE remains quite high catalytic activity in 28 days. This suggests that $\mathrm{Cu}_{2-\mathrm{x}} \mathrm{Se} \mathrm{CEs}$ are stable in polysulfide electrolyte. Considering the superb electrocatalytic activity and excellent stability, $\mathrm{Cu}_{2-\mathrm{x}} \mathrm{Se}$ has great potential to supersede the widely used $\mathrm{Cu}_{2} \mathrm{~S}$ in QDSSCs as a more effective CE catalyst with high stability. 
To further boost the efficiency of QDSSCs, the porous titania NHs [59] were employed to form the scattering layer instead of the commercial WER2-O Dyesol paste (with particle size of $150-250 \mathrm{~nm}$ ). As we previously reported, the use of porous titania NHs promoted the light
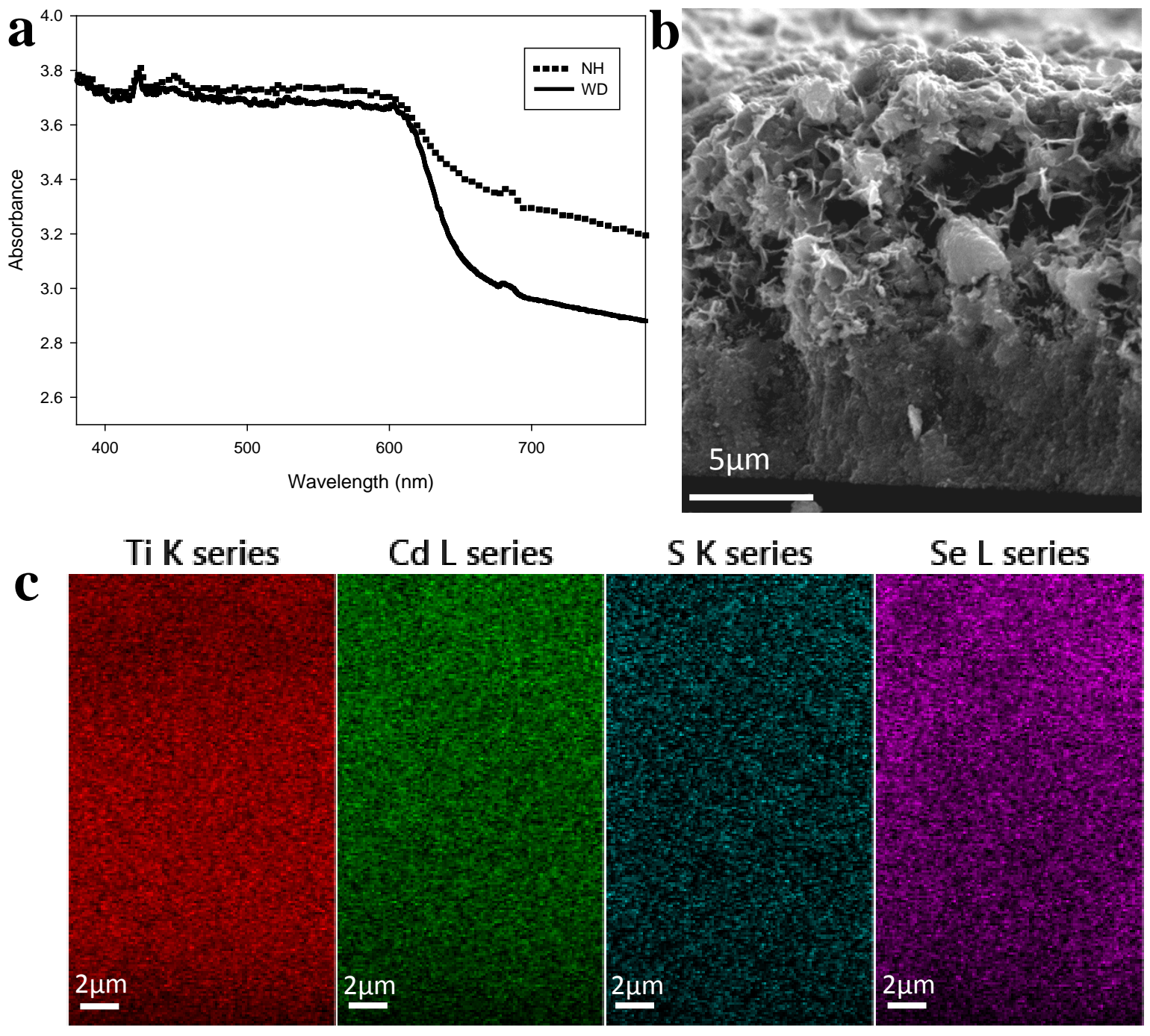

Figure 6. (a) Absorption spectra of QD-sensitized NH- and WD-TiO 2 films; (b) Crosssectional SEM image of QD-sensitized $\mathrm{TiO}_{2}$ film electrode consisting of a bottom transparent layer and a top NH scattering layer; (c) Elemental mapping of Ti, Cd, S, and Se by EDX spectroscopy showing the uniform distribution of the CdS/CdSe sensitizer throughout the film thickness.

scattering, QD loading, and charge transfer simultaneously [59], despite of the large particle size of up to micrometers. The darker color of $\mathrm{NH}$ film than $\mathrm{WD}^{-\mathrm{TiO}_{2}}$ film shown in Figure S10 indicates higher QD-loading which is due to the significantly enlarged surface area of 
NHs. In addition, QD-sensitized $\mathrm{NH}-\mathrm{TiO}_{2}$ film exhibited higher absorption than that of WD$\mathrm{TiO}_{2}$ film over the entire region (Figure 6a), which benefits the photocurrent of QDSSCs. To quantify the increased QD-loading, both QD-sensitized NH and WD films with a dimension of $c a .4 \mathrm{~cm}^{2}$ were used for ICP analysis. The Cd concentration in NH film was determined to be $1.21 \times 10^{-3} \mathrm{~mol} \mathrm{~cm}{ }^{2-}$, which is higher than that $\left(1.02 \times 10^{-3} \mathrm{~mol} \mathrm{~cm}^{2-}\right)$ in WD film. In addition, the uniformity of QD distribution throughout the NH film was examined by performing cross-sectional SEM with elemental mapping via EDX analysis. Figure $6 \mathrm{~b}$ and 6c shows the cross-sectional SEM image and elemental mapping of QD-sensitized NH film. The results demonstrated the uniform distribution of $\mathrm{Cd}, \mathrm{S}$, and Se atoms throughout the film. 

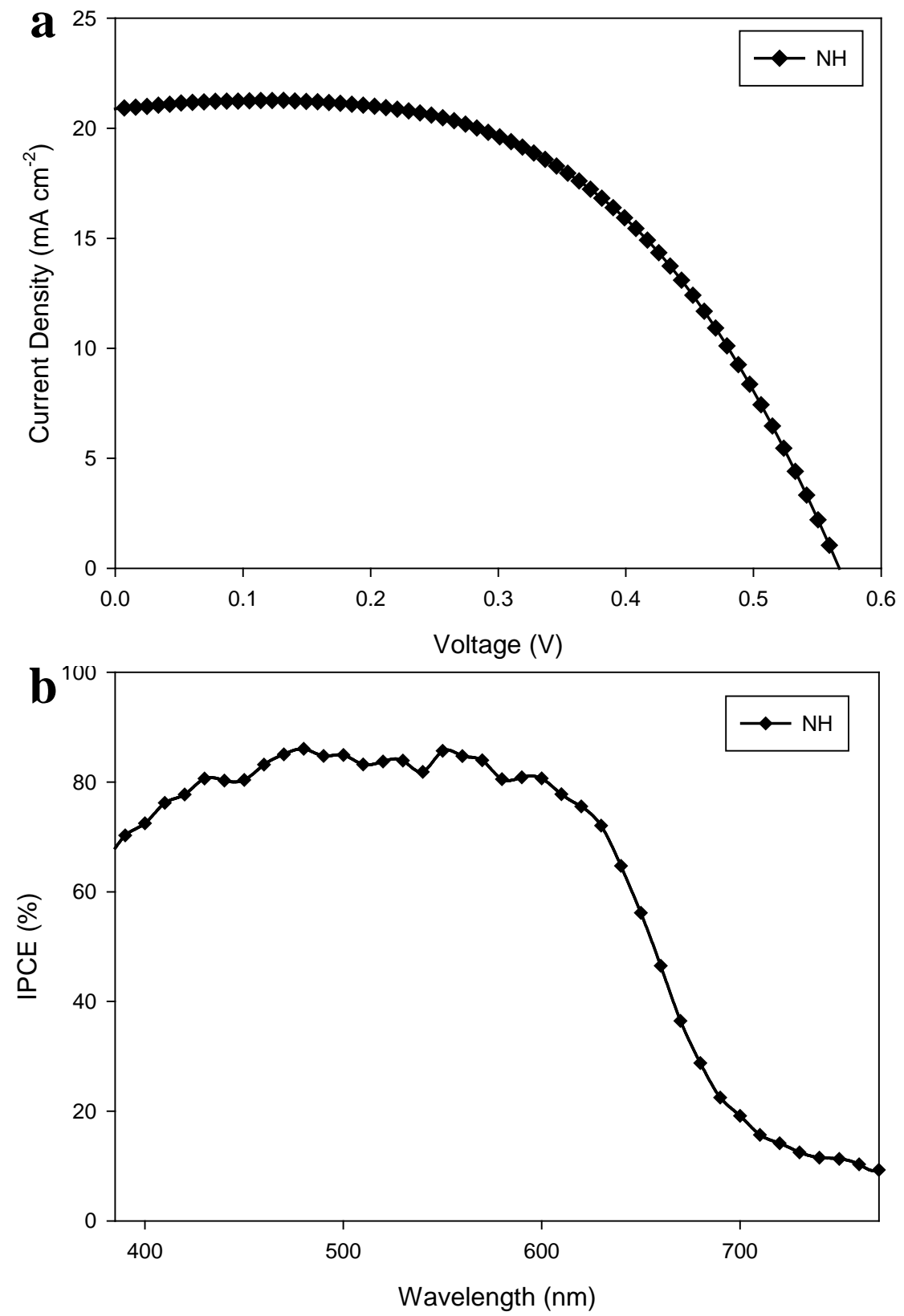

Figure 7. (a) Photocurrent density-voltage curve and (b) IPCE spectra of QDSSC fabricated with $\mathrm{NH}-\mathrm{TiO}_{2}$ photoanode and $\mathrm{Cu}_{2-\mathrm{x}} \mathrm{Se}$ NP CE measured under AM1.5 illumination $\left(100 \mathrm{~mW} \mathrm{~cm}{ }^{-2}\right)$

Table 2. Photovoltaic performance parameters of QDSSCs fabricated with $\mathrm{NH}-\mathrm{TiO}_{2}$ photoanodes and $\mathrm{Cu}_{2-\mathrm{x}} \mathrm{Se}$ NP CE.

\begin{tabular}{lclll}
\hline Samples & $J_{s c}\left(\mathrm{~mA} \mathrm{~cm}{ }^{-2}\right)$ & $V_{o c}(\mathrm{mV})$ & $F F(\%)$ & $\eta(\%)$ \\
\hline $\mathrm{NH}^{*}$ & 20.83 & 568 & 58.9 & 6.97 \\
$\mathrm{NH}$-champion & 21.39 & 567 & 58.6 & 7.11 \\
\hline
\end{tabular}

*The average value was obtained by testing 6 cells. 
The resultant QD-sensitized NH films were assembled with $\mathrm{Cu}_{2-\mathrm{x}} \mathrm{Se}$ NP CEs to construct QDSSC devices and the photocurrent density-voltage $(J-V)$ characteristics of these QDSSCs were shown in Figure 7a. As listed in Table 2, the efficiency was pronouncedly boosted to an average value of $6.97 \%$ with $J_{s c}$ of $20.83 \mathrm{~mA} \mathrm{~cm}^{-2}, V_{o c}$ of $568 \mathrm{mV}$, and $F F$ of $58.9 \%$. This can be ascribed to the synergetic effect of tri-functional NH photoanode and highly effective $\mathrm{Cu}_{2-\mathrm{x}} \mathrm{Se}$ NP CE. Figure 7b shows the IPCE spectrum for the NH-based QDSSCs. IPCEs of over $80 \%$ in the range of $420-620 \mathrm{~nm}$ were observed and maximum value of up to $86.5 \%$ was achieved. The further enhanced IPCE was mainly due to the higher QD-loading and better light scattering. The calculated $J_{s c}$ from the IPCE spectra is $19.2 \mathrm{~mA} \mathrm{~cm}^{-2}$, which is close to the measured photocurrent. The champion cell delivered a recorded efficiency of 7.11\% for CdS/CdSe QDs co-sensitized solar cells. It has been reported that hysteresis appears in some perovskite solar cells depending on the measurement of scanning directions. In order to check if hysteresis happens in our devices, we conducted the IV scan in both reverse and forward directions. As shown in Figure S11, no obvious hysteresis was observed in our devices by changing the sweep direction, which verified the reliable efficiency obtained.

\section{Conclusions}

In summary, new types of $\mathrm{Cu}_{2-\mathrm{x}} \mathrm{Se} \mathrm{NP}$ and $\mathrm{NW}$ catalysts were synthesized by facile wetchemical methods, which were subsequently used as CEs in QDSSCs via a scalable roll-toroll approach. The photovoltaic characteristics showed that the use of $\mathrm{Cu}_{2-\mathrm{x}} \mathrm{Se}$ NP CE can remarkably enhance the efficiency by $17.1 \%$ compared to $\mathrm{Cu}_{2} \mathrm{~S}$ CE. Both EIS and Tafelpolarization measurements verified that the resultant $\mathrm{Cu}_{2-\mathrm{x}} \mathrm{Se}$ CEs exhibited higher electrocatalytic activity in the reduction of polysulfide species than that of $\mathrm{Cu}_{2} \mathrm{~S} C E$ and $\mathrm{Au}$ CE. The good stability of $\mathrm{Cu}_{2-x}$ Se CEs was also demonstrated by EIS measurements over 
time. To further improve the efficiency, porous titania NHs were introduced as the scattering layer of the photoanode, leading to improved light scattering, QD-loading, and charge transfer at the same time. Eventually, an efficiency of 7.11\% for CdS/CdSe QDs cosensitized solar cell was achieved through simultaneous engineering of photocathode (highly effective $\mathrm{Cu}_{2-\mathrm{x}} \mathrm{Se} \mathrm{NP} \mathrm{CE}$ ) and photoanode (porous titania NHs). Our study may pave a way to the development of more effective $\mathrm{CE}$ as well as shed new insights for maximizing the efficiency enhancement of QDSSCs.

\section{Associated Content}

Supplementary figures. This material is available free of charge via the Internet

\section{Notes}

The authors declare no competing financial interest.

\section{Acknowledgements}

This work was financially supported by the Australian Research Council (ARC) through Discovery Projects (DP130102274, DP130102699) and Future Fellowship scheme (FT120100196). We also acknowledge the technical support from the Queensland node of the Australian National Fabrication Facility.

\section{References}

1. $\quad$ Kamat, P.V., J. Phys. Chem. C 2008. 112(48): p. 18737-18753.

2. $\quad$ Prabakar, K., S. Minkyu, S. Inyoung, and K. Heeje, J. Phys. D: Appl. Phys., 2010. 43(1).

3. Yu, W.W., L. Qu, W. Guo, and X. Peng, Chem. Mater., 2004. 16(3): p. 560-560.

4. $\quad$ Sambur, J.B., T. Novet, and B.A. Parkinson, Science, 2010. 330(6000): p. 63-66.

5. $\quad$ Nozik, A.J., Inorg. Chem., 2005. 44(20): p. 6893-6899.

6. $\quad$ Nozik, A.J., Chem Phys Lett, 2008. 457(1-3): p. 3-11.

7. $\quad$ Beard, M.C., J. Phys. Chem. Lett., 2011. 2(11): p. 1282-1288.

8. Semonin, O.E., J.M. Luther, S. Choi, H.-Y. Chen, J. Gao, A.J. Nozik, and M.C. Beard, Science, 2011. 334(6062): p. 1530-1533.

9. $\quad$ Pandey, A. and P. Guyot-Sionnest, J. Phys. Chem. Lett., 2009. 1(1): p. 45-47.

10. Tisdale, W.A., K.J. Williams, B.A. Timp, D.J. Norris, E.S. Aydil, and X.-Y. Zhu, Science, 2010. 328(5985): p. 1543-1547.

11. Hanna, M.C. and A.J. Nozik, J. Appl. Phys, 2006. 100(7).

12. Lee, Y.-L. and Y.-S. Lo, Adv. Funct. Mater., 2009. 19(4): p. 604-609. 
13. Ruhle, S., M. Shalom, and A. Zaban, ChemPhysChem, 2010. 11(11): p. 2290-2304.

14. Mora-Sero, I. and J. Bisquert, J. Phys. Chem. Lett., 2010. 1(20): p. 3046-3052.

15. Kamat, P.V., K. Tvrdy, D.R. Baker, and J.G. Radich, Chem. Rev., 2010. 110(11): p. 6664-6688.

16. Yang, Z., C.-Y. Chen, P. Roy, and H.-T. Chang, Chem. Commun., 2011.

17. O'Regan, B. and M. Gratzel, Nature, 1991. 353(6346): p. 737-740.

18. Kim, S., J.K. Lee, S.O. Kang, J. Ko, J.H. Yum, S. Fantacci, F. De Angelis, D. Di Censo, M.K. Nazeeruddin, and M. Grätzel, J. Am. Chem. Soc., 2006. 128(51): p. 16701-16707.

19. Grätzel, M., Acc. Chem. Res., 2009. 42(11): p. 1788-1798.

20. Mathew, S., A. Yella, P. Gao, R. Humphry-Baker, F.E. CurchodBasile, N. AshariAstani, I. Tavernelli, U. Rothlisberger, K. NazeeruddinMd, and M. Grätzel, Nat. Chem., 2014. 6(3): p. 242-247.

21. Kim, H.-S., C.-R. Lee, J.-H. Im, K.-B. Lee, T. Moehl, A. Marchioro, S.-J. Moon, R. Humphry-Baker, J.-H. Yum, and J.E. Moser, Sci. Rep., 2012. 2.

22. Lee, M.M., J. Teuscher, T. Miyasaka, T.N. Murakami, and H.J. Snaith, Science, 2012. 338(6107): p. 643-647.

23. Burschka, J., N. Pellet, S.-J. Moon, R. Humphry-Baker, P. Gao, M.K. Nazeeruddin, and M. Gratzel, Nature, 2013. 499(7458): p. 316-319.

24. Liu, D. and T.L. Kelly, Nat. Photonics., 2013.

25. Santra, P.K. and P.V. Kamat, J. Am. Chem. Soc., 2012. 134(5): p. 2508-2511.

26. Radich, J.G., N.R. Peeples, P.K. Santra, and P.V. Kamat, J. Phys. Chem. C 2014. 118(30): p. 16463-16471.

27. Tian, J., L. Lv, C. Fei, Y. Wang, X. Liu, and G. Cao, J. Mater. Chem. A, 2014.

28. Pan, Z., H. Zhang, K. Cheng, Y. Hou, J. Hua, and X. Zhong, ACS Nano, 2012. 6(5): p. 3982-3991.

29. Guijarro, N., T. Lana-Villarreal, I. Mora-Sero, J. Bisquert, and R. Gomez, J. Phys. Chem. C 2009. 113(10): p. 4208-4214.

30. Mora-Seró, I.n., S. Giménez, F. Fabregat-Santiago, R. Gómez, Q. Shen, T. Toyoda, and J. Bisquert, Acc. Chem. Res., 2009. 42(11): p. 1848-1857.

31. Bang, J.H. and P.V. Kamat, ACS Nano, 2009. 3(6): p. 1467-1476.

32. Salant, A., M. Shalom, I. Hod, A. Faust, A. Zaban, and U. Banin, ACS Nano, 2010. 4(10): p. 5962-5968.

33. Acharya, K.P., T.R. Alabi, N. Schmall, N.N. Hewa-Kasakarage, M. Kirsanova, A. Nemchinov, E. Khon, and M. Zamkov, J. Phys. Chem. C 2009. 113(45): p. 1953119535.

34. Zhang, Q., X. Guo, X. Huang, S. Huang, D. Li, Y. Luo, Q. Shen, T. Toyoda, and Q. Meng, Phys. Chem. Chem. Phys., 2011. 13(10): p. 4659-4667.

35. Niitsoo, O., S.K. Sarkar, C. Pejoux, S. Rühle, D. Cahen, and G. Hodes, J. Photochem. Photobiol., A, 2006. 181(2-3): p. 306-313.

36. Guijarro, N., T. Lana-Villarreal, Q. Shen, T. Toyoda, and R. Gomez, J. Phys. Chem. C 2010. 114(50): p. 21928-21937.

37. Wang, J., I. Mora-Seró, Z. Pan, K. Zhao, H. Zhang, Y. Feng, G. Yang, X. Zhong, and J. Bisquert, J. Am. Chem. Soc., 2013. 135(42): p. 15913-15922.

38. Gao, J., J.M. Luther, O.E. Semonin, R.J. Ellingson, A.J. Nozik, and M.C. Beard, Nano Lett., 2011. 11(3): p. 1002-1008.

39. Kuo, C.-Y., M.-S. Su, C.-S. Ku, S.-M. Wang, H.-Y. Lee, and K.-H. Wei, J. Mater. Chem. , 2011.

40. Noone, K.M., E. Strein, N.C. Anderson, P.T. Wu, S.A. Jenekhe, and D.S. Ginger, Nano Lett., 2010. 10(7): p. 2635-2639. 
41. Lee, J.-W., D.-Y. Son, T.K. Ahn, H.-W. Shin, I.Y. Kim, S.-J. Hwang, M.J. Ko, S. Sul, H. Han, and N.-G. Park, Sci. Rep., 2013. 3.

42. Jiang, Y., X. Zhang, Q.-Q. Ge, B.-B. Yu, Y.-G. Zou, W.-J. Jiang, W.-G. Song, L.-J. Wan, and J.-S. Hu, Nano Lett., 2013. 14(1): p. 365-372.

43. Kamat, P.V., Acc. Chem. Res., 2012. 45(11): p. 1906-1915.

44. Rühle, S., M. Shalom, and A. Zaban, ChemPhysChem, 2010. 11(11): p. 2290-2304.

45. Yang, Z.S., C.Y. Chen, C.W. Liu, and H.T. Chang, Chem. Commun., 2010. 46(30): p. 5485-5487.

46. Faber, M.S., K. Park, M. Cabán-Acevedo, P.K. Santra, and S. Jin, J. Phys. Chem. Lett., 2013. 4(11): p. 1843-1849.

47. Yang, Z., C.-Y. Chen, C.-W. Liu, C.-L. Li, and H.-T. Chang, Adv. Energy Mater., 2011. 1(2): p. 259-264.

48. Meng, K., P.K. Surolia, O. Byrne, and K.R. Thampi, J. Power Sources, 2014. 248(0): p. 218-223.

49. Radich, J.G., R. Dwyer, and P.V. Kamat, J. Phys. Chem. Lett., 2011. 2(19): p. 24532460.

50. Xu, J., X. Yang, Q.-D. Yang, T.-L. Wong, and C.-S. Lee, J. Phys. Chem. C 2012. 116(37): p. 19718-19723.

51. Tachan, Z., M. Shalom, I. Hod, S. Rühle, S. Tirosh, and A. Zaban, J. Phys. Chem. C 2011. 115(13): p. 6162-6166.

52. Yue, G., J. Wu, Y. Xiao, M. Huang, J. Lin, and J.-Y. Lin, J. Mater. Chem. A, 2013. 1(4): p. 1495-1501.

53. Lin, J.Y., C.Y. Chan, and S.W. Chou, Chem. Commun., 2013. 49(14): p. 1440-1442.

54. Fan, S.Q., B. Fang, J.H. Kim, J.J. Kim, J.S. Yu, and J. Ko, Appl. Phys. Lett., 2010. 96(6).

55. Kamat, P.V., J.A. Christians, and J.G. Radich, Langmuir, 2014. 30(20): p. 5716-5725.

56. Grozdanov, I., C.K. Barlingay, and S.K. Dey, Integr. Ferroelectr., 1995. 6(1-4): p. 205-211.

57. Choi, H.M., I.A. Ji, and J.H. Bang, ACS Appl Mater Interfaces, 2014. 6(4): p. 23352343.

58. Bo, F., C. Zhang, C. Wang, S. Xu, Z. Wang, and Y. Cui, J. Mater. Chem. A, 2014. 2(35): p. 14585-14592.

59. Bai, Y., Z. Xing, H. Yu, Z. Li, R. Amal, and L. Wang, ACS Appl Mater Interfaces, 2013. 5(22): p. 12058-12065.

60. Sasaki, T., M. Watanabe, H. Hashizume, H. Yamada, and H. Nakazawa, J. Am. Chem. Soc., 1996. 118(35): p. 8329-8335.

61. Sasaki, T. and M. Watanabe, J. Am. Chem. Soc., 1998. 120(19): p. 4682-4689.

62. Choy, J.H., H.C. Lee, H. Jung, H. Kim, and H. Boo, Chem. Mater., 2002. 14(6): p. 2486-2491.

63. Kim, T.W., S.G. Hur, S.J. Hwang, H. Park, W. Choi, and J.H. Choy, Adv. Funct. Mater., 2007. 17(2): p. 307-314.

64. Bai, Y., H. Yu, Z. Li, R. Amal, G.Q. Lu, and L.Z. Wang, Adv. Mater., 2012. 24(43): p. 5850-5856.

65. Huang, S.Q., Q.X. Zhang, X.M. Huang, X.Z. Guo, M.H. Deng, D.M. Li, Y.H. Luo, Q. Shen, T. Toyoda, and Q.B. Meng, Nanotechnology, 2010. 21(37).

66. Yang, Z., Q. Zhang, J. Xi, K. Park, X. Xu, Z. Liang, and G. Cao, Sci. Adv. Mater., 2012. 4(10): p. 1013-1017.

67. Bai, Y., X. Zong, H. Yu, Z.-G. Chen, and L. Wang, Chem. Eur. J. , 2014. 20(28): p. 8670-8676. 
68. García, V.M., P.K. Nair, and M.T.S. Nair, J. Cryst. Growth, 1999. 203(1-2): p. 113124.

69. Mora-Seró, I., S. Giménez, F. Fabregat-Santiago, R. Gómez, Q. Shen, T. Toyoda, and J. Bisquert, Acc. Chem. Res., 2009. 42(11): p. 1848-1857.

70. Guijarro, N., J.M. Campina, Q. Shen, T. Toyoda, T. Lana-Villarreal, and R. Gomez, Phys. Chem. Chem. Phys., 2011. 13(25): p. 12024-12032.

71. Huang, X., S. Huang, Q. Zhang, X. Guo, D. Li, Y. Luo, Q. Shen, T. Toyoda, and Q. Meng, Chem. Commun., 2011. 47(9): p. 2664-2666.

72. Hossain, M.A., J.R. Jennings, Z.Y. Koh, and Q. Wang, ACS Nano, 2011. 5(4): p. 3172-3181.

73. Murakami, T.N., S. Ito, Q. Wang, M.K. Nazeeruddin, T. Bessho, I. Cesar, P. Liska, R. Humphry-Baker, P. Comte, and P. Péchy, J. Electrochem. Soc., 2006. 153(12): p. A2255-A2261.

74. Chen, J., K. Li, Y. Luo, X. Guo, D. Li, M. Deng, S. Huang, and Q. Meng, Carbon, 2009. 47(11): p. 2704-2708.

75. Wu, M., X. Lin, A. Hagfeldt, and T. Ma, Angew. Chem. Int. Ed., 2011. 50(15): p. 3520-3524.

76. Fabregat-Santiago, F., J. Bisquert, E. Palomares, L. Otero, D. Kuang, S.M. Zakeeruddin, and M. Grätzel, J. Phys. Chem. C, 2007. 111(17): p. 6550-6560.

77. Wang, Q., J.-E. Moser, and M. Grätzel, J. Phys. Chem. B, 2005. 109(31): p. 1494514953.

78. Chen, X., Y. Hou, B. Zhang, X.H. Yang, and H.G. Yang, Chem. Commun., 2013. 49(51): p. 5793-5795.

79. Hauch, A. and A. Georg, Electrochim. Acta, 2001. 46(22): p. 3457-3466.

80. Zakeeruddin, S.M. and M. Grätzel, Adv. Funct. Mater., 2009. 19(14): p. 2187-2202.

81. Gong, F., H. Wang, X. Xu, G. Zhou, and Z.-S. Wang, J. Am. Chem. Soc., 2012. 134(26): p. 10953-10958. 